\title{
Drivers of sales performance: a contemporary meta-analysis. Have salespeople become knowledge brokers?
}

\author{
Willem Verbeke $\cdot$ Bart Dietz $\cdot$ Ernst Verwaal
}

Received: 10 March 2009/Accepted: 20 July 2010 /Published online: 12 August 2010

(C) The Author(s) 2010. This article is published with open access at Springerlink.com

\begin{abstract}
It has been 25 years since the publication of a comprehensive review of the full spectrum of salesperformance drivers. This study takes stock of the contemporary field and synthesizes empirical evidence from the period 1982-2008. The authors revise the classification scheme for sales performance determinants devised by Walker et al. (1977) and estimate both the predictive validity of its sub-categories and the impact of a range of moderators on determinant-sales performance relationships. Based on multivariate causal model analysis, the results make two major observations: (1) Five sub-categories demonstrate significant relationships with sales performance: selling-related knowledge $(\beta=.28)$, degree of adaptiveness $(\beta=.27)$, role ambiguity $(\beta=-.25)$, cognitive aptitude $(\beta=.23)$ and work engagement $(\beta=.23)$. (2) These sub-categories are moderated by measurement method, research context, and salestype variables. The authors identify managerial implications of the results and offer suggestions for further research,
\end{abstract}

Willem Verbeke and Bart Dietz contributed equally to the project.

\author{
W. Verbeke \\ Erasmus University Rotterdam, \\ Room H 15-27, P.O. Box 1738, NL-3000 Rotterdam, \\ The Netherlands \\ e-mail: verbeke@ese.eur.nl \\ B. Dietz $(\bowtie)$ \\ Erasmus University Rotterdam, \\ Room T 8-32, P.O. Box 1738, NL-3000 Rotterdam, \\ The Netherlands \\ e-mail: bdietz@rsm.nl \\ E. Verwaal \\ Erasmus University Rotterdam, \\ Room T 7-50, P.O. Box 1738, NL-3000 Rotterdam, \\ The Netherlands \\ e-mail: everwaal@rsm.nl
}

including the conjecture that as the world is moving toward a knowledge-intensive economy, salespeople could be functioning as knowledge-brokers. The results seem to back this supposition and indicate how it might inspire future research in the field of personal selling.

Keywords Sales performance $\cdot$ Salespeople .

Meta-analysis $\cdot$ Knowledge-economy $\cdot$ Knowledge-brokering

An understanding of the factors that drive sales performance and how these vary across different contexts is essential for both managers and researchers in sales and marketing. Twenty-five years ago Churchill et al. (1985) published a seminal paper on the antecedents of sales performance that has shaped academic and managerial thinking on sales management and become one of the most cited articles in marketing research (Leigh et al. 2001). Applying a classification scheme of antecedents of sales performance developed previously by Walker et al. (1977), Churchill et al. (1985) found six predictive categories to explain marginal variance in sales performance (in order of predictive validity): role perceptions, skill levels, aptitude, motivation, personal characteristics, and organizational/ environmental variables. In addition, their meta-analysis demonstrated that the type of products sold moderated the predictive power of these categories for sales performance. Most empirical research thus far had been looking at enduring personal characteristics as determinants for sales performance. The basic message of this meta-analysis was that these variables were not the most important predictors (Churchill et al. 1985, p. 117). Instead, Churchill et al. (1985) suggested that researchers should investigate "influenceable" determinants of sales performance. Another key focus they proposed was the dynamic nature of the sales 
conversation that indeed has become a crucial research topic (p. 116). This call sparked a plethora of new research streams on the determinants of sales performance. Twentyfive years have passed since then and, as Bass and Wind (1995, p. 1) mention, some marketing disciplines have "matured to the point where it seems desirable to take stock of where we are, [and] what we have learned" to develop research themes which might provide input for future research in selling. With novel research streams presently integrated into the extant literature on sales performance determinants, it is time for an appraisal of the field.

The Churchill et al. (1985) meta-analysis covered the field of sales performance research from 1918 to 1982 . We focus on the sales performance literature after this period, performing a meta-analysis to gain insights into the predictive power of sales-performance determinants across empirical research models of the past 25 years. In the interim, other meta-analyses have taken place. For instance, Vinchur et al. (1998) focused their analysis on the effect of personality traits on sales performance. However, our study has a broader aim; it assesses the full spectrum of salesperformance determinants that have been researched since Churchill et al. (1985). This paper makes a fourfold contribution: (1) We develop a theoretically refined version of the Walker et al. (1977) classification system. (2) We evaluate the predictive validity of sales-performance determinants across primary research models and correct our findings for artifacts (e.g., sampling error). Analyzing intercorrelations between antecedent categories, we estimate a two-stage structural equation model (TSSEM) to identify the independent effects of determinants on sales performance. (3) We present an analysis of the moderators of measurement method, research context, and sales-type variables. (4) We interpret the meaning of these salesperformance drivers in the context of recent developments in our economic landscape. Taking an overview of the data, we speculate that as we move toward a knowledgeintensive economy (e.g., Verbeke et al. 2008) or a science-based economy (e.g., Stremersch and Van Dyck 2009), salespeople will take on more of a knowledgebrokering role, transferring know-why (science behind products/services) and know-how (what salespeople learn when a market segment uses products/services) to customers (e.g., Stremersch and Van Dyck 2009; Verbeke et al. 2008). We discuss research topics that match this vision of the sales function of the future.

\section{Conceptual framework}

By importing significant behavioral science perspectives into sales force research, Walker et al. (1977) developed an integrative conceptual model of the antecedents of sales performance. Churchill et al. (1985) applied this model in their meta-analysis, dividing the determinants for sales performance into six main categories: role perceptions, aptitude, skill level, motivation, personal factors and organizational and environmental (see Table 1 for definitions). In general, this coarse-grained six-factor categorization scheme does not correspond with the widely fragmented full spectrum of sales performance determinants which, based upon our own reading of the primary studies, is used in this study. To enable us to engage in a finely grained exploration of sales-performance antecedents, we revised the Walker et al. (1977) categorization scheme by means of three reiterations, retaining their six-factor outline as a guide to our own meta-analysis. Our conceptual framework is shown in Fig. 1. First, we reviewed the literature in various theoretical fields, such as psychology and organizational behavior, focusing on prominent authors who have attempted to develop overall conceptual frameworks in their domains. Guided again by Walker et al. (1977), we used the theoretical frameworks of other scholars to develop sub-classifications in each of the six categories. Second, we evaluated the level at which our six refined categories accurately covered all critical streams of sales force research. Then we inserted additional subcategories to incorporate research streams that conceptually fit into the broader Walker et al. (1977) categories but do not fit clearly into any theoretical sub-category. As a third and final step in our revision process, we performed a theory-driven reiteration of the revised classification model, removing sub-categories in three instances: (1) we adapted definitions of sub-categories to increase their validity; (2) we merged sub-categories when differences between them were not meaningful to meta-analytic purposes; and (3) we deleted sub-categories when they showed conceptual overlap (redundancy). For example, Kanfer's (1990) model of work motivation contains a category for "needs-motivesvalues" that overlaps with the "personal concerns" category in the McAdams' (1995) aptitude model. To remove redundancy and improve category fit, we used the Walker et al. (1977) categorization. In what follows we motivate and describe our revised categorization model.

\section{Classification scheme}

Role perceptions When the Churchill et al. (1985) metaanalysis was published, their "role perceptions" category of sales performance determinants represented the most novel (no studies before 1976), and one of the smallest (4\% of total correlations) sub-categories (p. 106). Today, the body of empirical studies on role perceptions in selling is substantial. The work in this field is consistently dominated by three interrelated constructs that form the basis of our sub-classification (see Table 1 for definitions): role conflict, 
Table 1 Description of classification categories

\begin{tabular}{llll}
\hline Predictor & $\begin{array}{l}\text { Classical } \\
\text { hypothesis }\end{array}$ & Definition & Examples of included variables \\
\hline
\end{tabular}

Role Perceptions

Role Conflict

Role Ambiguity

Role Overload

Burnout

Aptitude

Dispositional Traits $\quad$ +/-

Personal Concerns $\quad+/-$

Identity $\quad+/-$

Cognitive +

Skill Level

Micro selling

Interpersonal

Degree of Adaptiveness

\section{Macro selling \\ Selling-Related \\ Knowledge}

\section{Motivation \\ Cognitive Choice}

Goal Orientation

$+$

Work Engagement

Personal

Biographical
Perceptions of demands and expectations by role partners (Walker et al. 1977)

The perception that expectations and demands of two or more role partners are mismatched (Singh 1998, p. 70)

Perceived lack of information to perform the job adequately and uncertainty about the expectations of different role set members (Singh 1998, p. 70)

Perception that the cumulative role demands exceed the abilities and motivation to perform a task (Singh 1998, p. 70)

A prolonged response to chronic emotional and interpersonal stressors on the job (Maslach et al. 2001, p. 397)

Native abilities and enduring personal traits relevant to the performance of job activities (Walker et al. 1977)

Broad, decontextualized and relatively non-conditional constructs which provide a dispositional signature for personality description (McAdams 1995, p. 365)

Personality descriptions that are contextualized in time, place or role (McAdams 1995, p. 365)

An internalized narrative of the self that incorporates the reconstructed past, perceived present, and anticipated future (McAdams 1995, p. 365)

Category that includes measures of a general factor of mental ability, verbal ability, and quantitative ability (Vinchur et al. 1998, p. 589)

Learned proficiency at performing necessary tasks for the sales job (Ford et al. 1983)

Skills related to understanding, persuading and getting along with other people such as customers (Ford et al. 1987, p. 104)

The altering of sales behaviors during a customer interaction or across customer interactions based on perceived information about the nature of the selling situation (Weitz et al. 1986, p. 175)

The depth and width of the knowledge base that salespeople need to size up sales situations, classify prospects, and select appropriate sales strategies for clients (Leong et al. 1989, p. 164)

The amount of effort a salesperson desires to expend on each activity or task associated with the job (Walker et al. 1977)

Cognitive processes that describe a deliberate choice for initiating, expending and persisting in expending effort over time on a certain task (Campbell and Pritchard 1976; Kanfer 1990, p. 82)

Underlying goals that people pursue in achievement situations (Sujan et al. 1994, p. 39)

A persistent positive affective-motivational state of fulfillment (Sonnentag 2003, p. 518)

Intra-individual factors that might be related to salespeople's performance but which are not part of the aptitude, skill level, motivation and role perceptions components (Churchill et al. 1985)

Variables that include demographic and psychical characteristics, experiences and aspects of the candidate's current family status and lifestyle thought to effect a person's potential performance (Ford et al. 1987)
Role Conflict

Role Problems

Role Ambiguity

Role Clarity (reversed)

Role Overload

Difficulty

Reduced Accomplishment

Emotional Exhaustion

Extraversion

Neuroticism

Need for Conformity

Other Directness

Self Perceived Ethicalness

Reciprocity

General Mental Ability (IQ)

Verbal Intelligence

Communication Skills

Presentation Skills

Adaptive Selling

Ability to Modify Sales

Presentations

Product / Technical Knowledge Customer Knowledge

Prior Goal Setting

Spending Time on a Specific Task

Learning Goal Orientation

Performance Goal Orientation

Enthusiasm

Citizenship Behaviors

Age

Sales Experience 
Table 1 (continued)

\begin{tabular}{|c|c|c|c|}
\hline Predictor & $\begin{array}{l}\text { Classical } \\
\text { hypothesis }\end{array}$ & Definition & Examples of included variables \\
\hline $\begin{array}{l}\text { Organizational \& } \\
\text { Environmental }\end{array}$ & & $\begin{array}{l}\text { Factors such as variations in territory potential and strength } \\
\text { of competition (Ford et al. 1983) }\end{array}$ & \\
\hline External Environment & $+/-$ & $\begin{array}{l}\text { The external environment faced by salespeople (Ford et al. } \\
1983 \text {, p. 374) }\end{array}$ & $\begin{array}{l}\text { Market Competition } \\
\text { Prospect Income }\end{array}$ \\
\hline Internal Environment & $+/-$ & $\begin{array}{l}\text { A broad range of organizational characteristics and social } \\
\text { relationships which constitute the person's work } \\
\text { environment (Ford et al. 1983, p. 375) }\end{array}$ & $\begin{array}{l}\text { Marketing Orientation } \\
\text { Flexibility }\end{array}$ \\
\hline Supervisory Leadership & + & $\begin{array}{l}\text { The extent of sales managers' monitoring, directing, } \\
\text { evaluating, and rewarding activities (Anderson and } \\
\text { Oliver 1987, p. 76) }\end{array}$ & $\begin{array}{l}\text { Positive Feedback } \\
\text { Transformational Leadership }\end{array}$ \\
\hline
\end{tabular}

role ambiguity, and role overload (Singh et al. 1994; Singh 1998). Role conflict is the perceived mismatch between requirements and expectations of the various role partners with whom salespeople interact. Role ambiguity takes place when salespeople feel that they have insufficient information to perform effectively and when they are uncertain about the expectations of role partners. Role overload is the perceived surplus of job demands in comparison to perceived personal motivation and abilities.

In addition to studying the impact of independent role stressors, scholars have found a cumulative impact of multiple role stressors on sales performance (Singh et al. 1994). Besides examining the direct effects of stressors on sales performance, researchers have also been looking at the effects of more prolonged responses to stressors in the sales job. To capture these role stress-related variables we added the sub-category of burnout to our model (Maslach et al. 2001). The extant literature regarding role stressors agrees that role conflict, role ambiguity, role overload and burnout are inversely related to sales performance (e.g., Bagozzi 1978; Behrman and Perreault 1984; Brown and Peterson 1993; Mackenzie et al. 1998; Singh et al. 1994).

Aptitude Churchill et al. (1985, p. 116) took their relatively widespread "aptitude" category as an example of one in need of refinement. For our revision we drew on the work of McAdams (1993, 1995, 1996) that identifies traits, concerns and identity as three most distinctive levels of human individuality. Building on the McAdams (1995) taxonomy, we refined aptitude with three sub-categories: (1) dispositional traits capture decontextualized, dispositional dimensions of personality such as "extraversion" or
Fig. 1 Conceptual model of the meta-analysis

\begin{tabular}{|c|}
\hline 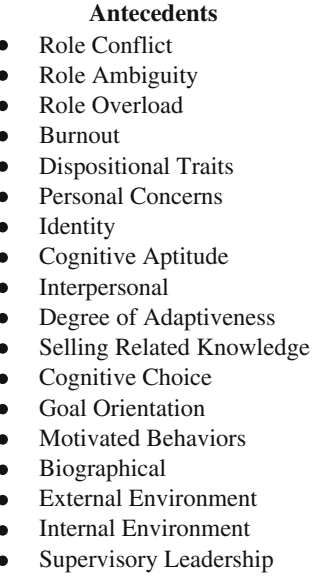 \\
\hline
\end{tabular}

Measurement Method Moderators

- Self versus managerial report

- Objective data versus managerial report

- Multi-item versus single-item measure

Research Context Moderators

- Service versus goods

- Consumers versus business customers

- Internal versus external governance

\section{Sales Type Moderators}

- Output versus behavior

- Relationship quality versus traditional 
"neuroticism." (2) Personal concerns represent contextualized needs and individual need-fulfillment strategies such as a salesperson's work-related "need for growth" or "need for achievement." (3) Identity, defined as "an internalized narrative of the self that incorporates the reconstructed past, perceived present and anticipated future" (McAdams 1995, p. 365), represents personality variables such as "self perceived ethicalness" and "self esteem." To conclude our refinement, we built on the meta-analytical taxonomy of Vinchur et al. (1998) and added a fourth sub-dimension of cognitive aptitudes to include general mental ability (IQ) variables in the aptitude category. The literature agrees that general cognitive abilities have a positive effect on sales performance (Hunter and Hunter 1984). However, the effects of the other personality variables on sales performance are highly inconsistent in their conceptual direction.

Skill level Rentz et al. (2002, p. 13) argue that the considerable amount of research focused on selling skills since Churchill et al.'s (1985) meta-analysis can be classified into two primary areas: (1) A micro-skill stream distinguishes between three types of skills or capabilities in turn- "interpersonal skills," such as knowing how to cope with and resolve conflicts; "salesmanship skills," such as knowing how to make a presentation; and "technical skills," such as knowledge of product features and benefits. (2) A macro-skill stream concentrates on knowledge and knowledge-related capacities of salespeople (e.g., quantity and information richness of memorized customer categories). We based our revision of the skills category on the Rentz et al. (2002) model and introduced new subcategories for interpersonal skills, salesmanship skills, technical skills (micro-skills) and selling-related knowledge (macro-skills). In the second iteration we made two further adjustments: (1) A closer look at the conceptualization of the salesmanship skills category revealed a strong focus on salesperson adaptability. Given the importance of salesperson adaptability in the selling literature, we replaced the salesmanship skills category with a new category of degree of adaptiveness. And (2) a closer inspection of the technical skills category (including such variables as knowledge about product features and knowledge about customers) motivated us to merge "technical skills" with the "sellingrelated knowledge" to capture the idea that selling involves knowledge-based solutions for customers. The term "selling-related knowledge" thus captures the quantity and richness of knowledge that salespeople use in selling the products and services of the selling firm in ways that might help solve customer problems across different industries (e.g., Kumar et al. 2008).

Motivation Ambrose and Kulik (1999, p. 278) argued, "Organizational behavior research in the 1990s has largely abandoned the unitary concept of motivation and replaced this broad concept with more specific measures." In an extensive review of work-motivation literature, Kanfer (1990) proposed a triadic taxonomy of motivation consisting of three related paradigms. These drive our category revision: (1) need-motive-value emphasizes the role of personality, stable disposition and values as the basis for behavioral variability; (2) cognitive choice focuses on cognitive processes involved in decision making and choice; and (3) self-regulation metacognition is conceptualized as theories that focus on the motivational processes underlying goal-directed behaviors. To capture subcategories representing important motivation-related research domains in the field of selling that fall beyond the scope of the triadic Kanfer model (1990), we included two sub-categories. First, goal orientations, defined as "underlying goals that people pursue in achievement situations" (Sujan et al. 1994, p. 39). Second, work engagement, defined as "a persistent positive affective-motivational state of fulfillment" (Sonnentag 2003, p. 518). This is because, in addition to Kanfer's (1990) cognitive-driven conceptualization of motivation, sales research has investigated the effects of motivational sales performance determinants that are revealed when salespeople put in more work. This new sub-category reflects the current view in organizational behavior that employees can be conceived as proactive agents who display personal initiative, improve current circumstances, and/or create new ones (e.g., Sonnentag 2003). Work engagement includes such concepts as enthusiasm, job involvement, dedication to working harder, but also the willingness to do something extra for the firm (citizenship behaviors). Due to the conceptual incorporation of needs-motives-values (personal concerns) in our "aptitude" category and a relative absence or marginal existence of primary studies that relate self-regulation variables to sales performance, we deleted both categories from our typology of motivation.

Personal factors Shortly after the appearance of their metaanalysis in 1985, Ford et al. (1987, p. 90) reflected on their work: "The broad focus of that study ... precluded detailed exploration of the managerial implications of any specific factor or set of factors." To overcome this limitation, they performed a focused meta-analysis on the "personal and psychological" characteristics of salespeople. Ford et al. (1987, p. 92) distinguish performance-related personal variables into two sub-areas that they claim cover the most commonly used selection criteria for salespeople by practitioners: "biographical" and "psychological" variables. We drew from the Ford et al. (1987) distinction and incorporated a category of biographical variables in our classification scheme. However, a closer look at Ford et al.'s (1987) "psychological" variables shows that they 
include (a) various aptitudes or mental abilities, (b) personality traits and (c) learned skills and proficiencies. As aptitudes and personality traits both fall into our "aptitude" category and learned skills fall into our "skill" category, we deleted the psychological variables category and thus revised the broader Walker et al. (1977) "personal variables" category into a more specifically defined biographical variables category. The extant literature testing effects of biographical variables on sales performance shows highly inconsistent results (e.g., Brown et al. 2002; Warr et al. 2005) with regard to predictive validity.

Organizational and environmental A striking observation in the Churchill et al. (1985) meta-analysis is that scholars in the 1918-1982 timeframe had only marginally investigated the effects of organizational and environmental factors on sales performance (p. 110). This is in sharp contrast to current practices in salesforce research and the extant literature in strategic management where variables outside (environmental) and within (organizational) the organization are known to have dissimilar effects on performance (e.g., Chakravarthy and Doz 1992). Jaworski (1988) conceptualized the environmental context of a marketing unit into three types: macro environment (social, political, regulatory, economic, and technological conditions), operating environment (interest groups such as customers or suppliers with whom the firm deals directly), and internal environment. Whereas the macro and operating environments consist of variables in the external environment (e.g., economic uncertainty), the internal environment deals with aspects inside the firm (e.g., financial wellbeing). We drew on the Jaworski (1988) framework for our classification scheme with two adjustments. First, we merged the macro and operating environment categories, since they both fall outside the domain of the organization and salesforce researchers have not been distinguishing between these two forms of external environment. Second, we further refined the internal environment category with a sub-category of supervisory leadership behaviors (Kohli 1989) to isolate supervisory behaviors (e.g., providing feedback and leadership style) from those factors that are within the firm's official jurisdiction (Kohli 1989, p. 26) in nature but not directly related to supervisory behaviors (e. g., task characteristics and innovativeness of organizational culture). Extant literature agrees that supervisory behaviors have a positive effect on sales performance (e.g., Cravens et al. 2004; Kohli 1989). However, the effects of organizational and environmental variables are inherently inconsistent in the direction of their influence on sales performance (the direction of the effects on sales performance cannot be determined a priori). Table 1 describes the proposed classification model and classical hypotheses for the drivers of sales performance.

\section{Method}

Collection of studies

The Churchill et al. (1985) meta-analysis on selling for the period 1918-1982 represents state-of-the-art of generalizable knowledge on the determinants of salesperson performance. As a logical point of reference, we thus took 1982 as our starting point, and searched for published and unpublished empirical research on salesperson performance of the period 1982-2008. To identify a population of contemporary studies of salesperson performance, we conducted keyword searches in electronic databases (ABI Inform, Blackwell Synergy, Business Source Premier, EconLit, Emerald, JSTOR, ScienceDirect, SwetsWise, and PsychInfo) using keywords such as "sales," "performance," "salespeople," "selling," "effectiveness" and so forth. We searched for citations in seminal studies and did manual searches in leading marketing, management and organizational behavior journals likely to publish quality articles on determinants of salesperson performance (Journal of Marketing, Journal of Marketing Research, Journal of Personal Selling and Sales Management, Journal of the Academy of Marketing Science, Journal of Business Research, Journal of Applied Psychology, Marketing Science and Academy of Management Journal). With regard to unpublished empirical work, we searched online databases including Dissertation Abstracts International, UMI Dissertation Abstracts, and Social Science Research Network (SSRN), and browsed the databases of four leading business school libraries for dissertations (Harvard, Yale, MIT, and Stanford). We wrote to some 20 sales researchers, requesting working papers and forthcoming articles and issued a call for papers through the ELMAR list service to solicit non-published studies on salesperson performance. When the collection process ended (after culling obviously irrelevant matter such as book reviews, editorials and news items), we had identified and obtained 389 studies.

We then conducted a more detailed assessment and only included studies in our meta-analysis if they: (1) measured salesperson performance, and (2) reported one or more empirical determinant-performance relationships. After carefully screening the original 389 studies, we deleted 121 studies that did not meet our criteria for inclusion. ${ }^{1}$ Most of these (65 studies) measured performance on levels other than the individual salesperson (e.g., organizational).

\footnotetext{
${ }^{1}$ A list of studies included in our meta-analysis is available from the second author. The volume of our dataset is relatively high, compared to other meta-analyses in marketing (e.g., Henard and Szymanski 2001; Kirca et al. 2005). The inclusion rate of $69 \%$ is common in marketing meta-analyses (Kirca et al. 2005, p. 27).
} 
Next, studies were excluded if they were based on data used in already included studies (two studies). We also excluded conceptual articles (46 studies) without any quantitative analyses. Finally, 11 studies indicated that performance had been measured (meeting our first criterion), but did not report empirical results (violating our second criterion). Because correlations were the most common $(>95 \%)$ effect-size metric included in other studies, we e-mailed requests for correlation matrices to the first authors, which allowed us to save three of these studies and delete the remaining eight. Our efforts eventually yielded a final set of 268 studies. The majority of the studies report results for a single sample of salespeople; however, 24 articles reported data for multiple samples of salespeople (e.g., Wang and Netemeyer 2002). We treated the effect sizes from these different samples as independent observations in our database. This way we were able to assign other study descriptors (e.g., sample size) specifically to each effect size. In addition to salespeople, 23 studies included customers as informants in the study. Overall, the 268 studies reported 292 samples, representing 79,747 salespeople from 4,317 organizations.

\section{Effect size metric and coding}

Effect size metric Consistent with numerous meta-analyses in marketing (e.g., Geyskens et al. 1998; Henard and Szymanski 2001; Janiszewski et al. 2003; Kirca et al. 2005; Palmatier et al. 2006), we used correlations (i.e., the $r$ family of effect sizes, Rosenthal 1995, p. 185) as the metric for our meta-analysis. ${ }^{2}$ After reviewing the studies, we recorded 2,043 correlations. When effect sizes were reported with metrics other than correlations, we converted them into correlations if possible using conversion formulas by Glass et al. (1981). This resulted in the inclusion of 62 additional correlations. Finally, we inserted and classified 2,105 correlations in our database.

Coding procedure We designed a hard-copy coding form to register all necessary study-level and effect-size information for each study (Lipsey and Wilson 2001, pp. 73-90). All studies were coded in four steps. (1) We searched for reported

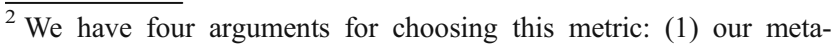
analysis involves bivariate associations between sales performance and its determinants (i.e., categories), which represent relationships where both variables are continuous, and correlation coefficients are "straightforwardly appropriate" (Lipsey and Wilson 2001, p. 63); (2) correlations were the most common metric reported in the studies (>95\%); (3) correlations can easily be computed from $t$ - or $F$-statistics; and (4) correlation coefficients are scale and unit-free and relatively easy to interpret (Geyskens et al. 1998, p. 230; Janiszewski et al. 2003, p. 140) as they are inherently standardized (Lipsey and Wilson 2001, p. 63).
}

determinants, reliability measures, effect sizes (i.e., correlations) and study descriptors (required for moderator analyses) and manually filled out coding forms. (2) We entered all data into a database. (3) The first author carefully investigated the theoretical definitions and construct operationalizations (if reported) of the 2,105 determinants, and classified each into one of the 18 sub-categories of our classification scheme (see Table 1). ${ }^{3}$ (4) For the classification of both determinants and moderators, we checked for coder reliability (Perreault and Leigh 1989). Following the double-coding procedure suggested by Lipsey and Wilson (2001), the second and third authors both classified random sub-samples of 437 determinants $(20 \%)$, and coded study-level nominal data on measurement methods, research context and sales types from a random sub-sample of 54 studies (20\%). In both cases, differences were resolved through discussion (Szymanski and Henard 2001). No significant discrepancies between coders were found (overall agreement $>95 \%$ ). We applied Huffcutt and Arthur's (1995) method for outlier identification in metaanalyses and discarded 30 correlations $(<2 \%)$ before proceeding with further analysis. To assess the plausibility of a file drawer problem, we calculated the fail-safe $N$ (Rosenthal 1979), which represents the number of unlocated studies with null results needed to reduce the cumulated effect across studies to the point of non-significance.

Level of analysis We took the individual effects as the unit of analysis. However, as the individual effects are nested in studies, our meta-analysis is hierarchically structured (Gurevitch and Hedges 1999). Many of the correlations occur only in one category (of our conceptual model) per study. However, 1,396 correlations occur at least twice in a similar category in a particular study. To justify the use of individual effects as the unit of analysis, we ran a $Q$-statistic test for heterogeneity (Hedges and Olkin 1985), which showed significant heterogeneity of correlations in studies $\left(\chi_{1395}{ }^{2}=14935.4 ; p<.01\right)$.

\section{Bivariate analysis}

To assess the strength of bivariate associations, we calculated the simple average of the correlations for each determinant. However, informed by literature on metaanalytic methods (Hunter and Schmidt 2004) and consistent with numerous marketing meta-analyses (e.g., Kirca et al. 2005; Palmatier et al. 2006), we adjusted the raw cor-

\footnotetext{
${ }^{3}$ In coding correlations, we encountered variables conceptualized in contrary to the suitable category. We managed this by recoding those variables in the same conceptual direction as the category. For example, Role Clarity correlations with salesperson performance were recoded to fit the conceptual category of Role Ambiguity. This led to the recoding of 51 correlations from a positive to a negative direction, and 54 correlations from a negative to a positive direction.
} 
relations (r) for reliability and weighed them for sample size to minimize potential differences with the "true" correlation that is free of artifacts. We adjusted the correlations for error of measurement of the determinants as well as salesperson performance by multiplying the square root of their reliabilities and then dividing the effect size by that "attenuation factor" to obtain the reliability-adjusted mean (Hunter and Schmidt 2004). We then corrected for sampling error by weighing each adjusted correlation according to the number of salespeople in the sample to determine the reliability-adjusted, sample-size-weighted mean and their $95 \%$ confidence intervals. While it is rare to find metaanalytic datasets that provide sufficient information to perform individual artifact corrections per study (Hunter and Schmidt 2004), our database allowed us to correct correlations individually for artifacts in most cases $(>90 \%)$, and for mean artifact distributions in remaining instances. Table 2 demonstrates the descriptives and means of our coded meta-analytic database.

\section{Multivariate causal model analysis}

Bivariate analysis reveals statistical associations but has the disadvantage of analyzing all associations separately. Therefore, we combined the bivariate analysis with a multivariate causal model analysis that analyzed all associations simultaneously, taking into account how antecedents are correlated. Based on aggregation of the 268 studies in our dataset, we constructed a pooled correlation matrix through pairwise deletion (e.g., Brown and Peterson 1993; Premack and Hunter 1988). The advantage of pairwise deletion is that the pooled correlation matrix includes all available studies (Cheung and Chan 2005). As is common in meta-analyses, the pooled correlation matrix included many cells for which we found no or only few observations. We decided to analyze only those relationships for which at least three intercorrelations were reported (Palmatier et al. 2006). Five antecedents met this criterion and were included in the multivariate causal model (Table 3).

A possible concern in analyzing a pooled correlation matrix in meta-analysis is that it suffers from heterogeneity (e.g., Viswesvaran and Ones 1995). Adopting Cheung and Chan's method (2005) to address this issue, we could not reject the hypothesis that the pooled correlation matrix is homogeneous. ${ }^{4}$ Thus, we used the pooled correlation matrix

\footnotetext{
${ }^{4}$ Cheung and Chan (2005) propose a method and provide statistical software (http://courses.nus.edu.sg/course/psycwlm/Internet) to test homogeneity of correlation matrices using the decision rule that follows from the following equation: $\min (\mathrm{Pij})<\alpha /(\mathrm{p}(\mathrm{p}-1) / 2)$, and $i \neq j$, where $\mathrm{p}_{\mathrm{ij}}$ is the observed probability value, a is the significance level, and $p$ is the number of variables. If at least one of the observed probability values is smaller than the significance level adjusted for multiple comparisons, the hypothesis of homogeneity is rejected.
}

to fit the multivariate causal model, using least squares estimation to estimate Eq. 1:

$\mathrm{SP}=\alpha_{1} \mathrm{X}_{1}+\alpha_{2} \mathrm{X}_{2}+\ldots+\alpha \mathrm{j} \mathrm{Xj}+\varepsilon$,

where SP is sales performance, $X_{i}$ are the drivers of performance, and $\alpha_{i}$ represent parameter estimates. Inherent to the pairwise deletion procedure, the number of observations (i.e., salespeople) varies per cell of the pooled correlation matrix (see Table 3). However, in meta-analytic structural equation modeling, researchers specify a sample size equal across cells (Viswesvaran and Ones 1995, p. 877). Thus, we used an equal number of observations per cell as a sample size in the multivariate causal model analysis. This approach is consistent with many other meta-analyses in marketing, which assume an equal number of observations across cells (while the intercorrelations matrices report varying numbers of observations between cells) to fit their models (e.g., Kirca et al. 2005, p. 29; Palmatier et al. 2006, p. 142). We fitted our model according to the harmonic mean of the sample sizes across studies $(n=179)$, because the harmonic mean takes the overall degree of the precision of the data into account and has no undue influence on studies with larger sample sizes (Viswesvaran and Ones 1995, p. 877).

\section{Moderator analysis}

Table 2 shows a wide range of values for many of the drivers of sales performance. To detect potential moderators, we applied the chi-square method as suggested by Hunter and Schmidt (2004), and found that significant variability across effect sizes exists for all 18 sub-categories (see $Q$-statistics). We performed dummy-variable regression to estimate moderators (e.g., Tellis 1988) with the following regression model (Eq. 2):

$$
\begin{aligned}
\mathrm{r}_{\mathrm{SP}, \mathrm{d}}= & \mu+\varphi_{1} \mathrm{Y}_{1}+\varphi_{2} \mathrm{Y}_{2}+\varphi_{3} \mathrm{Y}_{3}+\varphi_{4} \mathrm{Y}_{4}+\varphi_{5} \mathrm{Y}_{5} \\
& +\varphi_{6} \mathrm{Y}_{6}+\varphi_{7} \mathrm{Y}_{7}+\varphi_{8} \mathrm{Y}_{8}+\varepsilon,
\end{aligned}
$$

where $r_{S P, d}$ is the z-transformed value of the corrected correlation between sales performance and the respective determinant $d, \varphi_{i}$ are parameter estimates, and $Y_{i}$ are the following dummy-coded categorical variables. The variables $Y_{1}-Y_{3}$ represent sales performance measurement methods: $Y_{1}=$ self-report (1) versus managerial report (0); $\mathrm{Y}_{2}=$ objective data (1) versus managerial report (0); $\mathrm{Y}_{3}=$ multi-item (1) versus single-item measure (0). The variables $\mathrm{Y}_{4}-\mathrm{Y}_{6}$ represent research contexts: $\mathrm{Y}_{4}=$ services (1) versus goods ( 0 ); $Y_{5}=$ consumers (1) versus business customers (0); $\mathrm{Y}_{6}=$ internal (1) versus external governance (0). The variables $Y_{7}-Y_{8}$ represent sales types: $Y_{7}=$ output (1) versus behavior (0); $Y_{8}=$ relationship quality (1) versus traditional $(0)$. 
Table 2 Overview of drivers of sales performance

\begin{tabular}{|c|c|c|c|c|c|c|c|c|c|}
\hline \multirow[t]{2}{*}{ Predictor } & \multirow[t]{2}{*}{$\begin{array}{l}\text { Number of } \\
\text { raw effects }\end{array}$} & \multirow[t]{2}{*}{$\begin{array}{l}\text { Total } \\
\mathrm{N}\end{array}$} & \multirow[t]{2}{*}{$\begin{array}{l}\text { Simple } \\
\text { average } r^{a}\end{array}$} & \multirow[t]{2}{*}{$\begin{array}{l}\text { Average } r \\
\text { adjusted for } \\
\text { reliability }\end{array}$} & \multirow{2}{*}{$\begin{array}{l}\text { Reliability- } \\
\text { adjusted } \\
\text { sample-weighted } \\
\text { average } \mathrm{r}^{\mathrm{b}}\end{array}$} & \multirow[t]{2}{*}{ Z-value } & $\begin{array}{l}95 \% \\
\text { Confidence } \\
\text { interval }\end{array}$ & \multirow[t]{2}{*}{$\begin{array}{l}\text { File } \\
\text { drawer } \\
\mathrm{N}^{\mathrm{c}}\end{array}$} & \multirow[t]{2}{*}{$\begin{array}{l}\text { Q statistic for } \\
\text { homogeneity } \\
\text { test }^{d}\end{array}$} \\
\hline & & & & & & & $\begin{array}{l}\text { Lower Upper } \\
\text { bound bound }\end{array}$ & & \\
\hline
\end{tabular}

Role Perceptions

\begin{tabular}{|c|c|c|c|c|c|c|c|c|c|c|}
\hline Role Conflict & 57 & 12750 & -.11 & -.14 & -.15 & -1.12 & -.39 & .11 & n.a. & $18.7^{*}$ \\
\hline Role Ambiguity & 113 & 27832 & $-.21 *$ & $-.29 *$ & $-.25^{*}$ & -1.99 & -.57 & -.01 & 249 & $228.6^{*}$ \\
\hline Role Overload & 22 & 4582 & .02 & .02 & .07 & .11 & -.37 & .42 & n.a. & $181.3^{*}$ \\
\hline Burnout & 39 & 8709 & -.15 & -.20 & -.12 & -1.13 & -.56 & .15 & n.a. & $33.8^{*}$ \\
\hline \multicolumn{11}{|l|}{ Aptitude } \\
\hline Dispositional Traits & 125 & 27445 & .07 & .08 & .06 & .41 & -.31 & .48 & n.a. & $3578.9^{*}$ \\
\hline Personal Concerns & 34 & 8476 & .11 & .15 & .20 & .92 & -.16 & .45 & n.a. & $256.1 *$ \\
\hline Identity & 109 & 26489 & .14 & .16 & .13 & .75 & -.26 & .57 & n.a. & $2505.1 *$ \\
\hline Cognitive & 12 & 1928 & $.18^{*}$ & $.24 *$ & $.23 *$ & 2.04 & .01 & .45 & 3 & $209.3^{*}$ \\
\hline \multicolumn{11}{|l|}{ Skill Level } \\
\hline Interpersonal & 201 & 42615 & .21 & .27 & .24 & 1.37 & -.12 & .65 & n.a. & $9641.3^{*}$ \\
\hline Degree of Adaptiveness & 71 & 14547 & $.26^{*}$ & $.29 *$ & $.27 *$ & 1.95 & .00 & .59 & 14 & $412.4^{*}$ \\
\hline Selling-Related Knowledge & 122 & 29910 & $.26^{*}$ & $.33^{*}$ & $.28 *$ & 1.92 & -.01 & .67 & 20 & $2256.4^{*}$ \\
\hline \multicolumn{11}{|l|}{ Motivation } \\
\hline Cognitive Choice & 102 & 22989 & .15 & .19 & .20 & .92 & -.21 & .59 & n.a. & $1764.9^{*}$ \\
\hline Goal Orientation & 129 & 26460 & .18 & .23 & .21 & 1.58 & -.07 & .53 & n.a. & $1245.5^{*}$ \\
\hline Work Engagement & 110 & 25238 & .24 & .28 & .23 & 1.42 & -.11 & .67 & n.a. & $1133.6^{*}$ \\
\hline \multicolumn{11}{|l|}{ Personal } \\
\hline Biographical & 190 & 44948 & .10 & .12 & .12 & .69 & -.21 & .45 & n.a. & $7549.1^{*}$ \\
\hline \multicolumn{11}{|c|}{ Organizational \& Environmental } \\
\hline External Environment & 110 & 19506 & .17 & .20 & .12 & 1.02 & -.18 & .59 & n.a. & $945.7^{*}$ \\
\hline Internal Environment & 255 & 69625 & .15 & .19 & .16 & 1.04 & -.17 & .54 & n.a. & $9357.6^{*}$ \\
\hline Supervisory Leadership & 242 & 49204 & .17 & .20 & .17 & 1.15 & -.14 & .54 & n.a. & $2920.4^{*}$ \\
\hline
\end{tabular}

$* p<.05$

${ }^{a}$ Unadjusted for artifacts and not weighted for sample size.

b Reliability adjustments are based on individual study reliabilities. In those cases where this data was not available, it is based on the reliability distribution.

${ }^{c}$ The file drawer $N$ represents the number of unlocated studies with null results needed to reduce the cumulated effect across studies to the point of nonsignificance ( $p \geq .05$ ). In this column, "n.a." refers to the corresponding non-significant mean $\mathrm{r}$, which makes it unnecessary to estimate a file drawer $N$.

d The $Q$-statistic is used to test for homogeneity in the true correlations within each category.

\section{Moderators}

We now present hypotheses on why the strength of determinant-sales performance associations may vary across measurement methods, research contexts and sales types empirically explored by scholars in the field of sales performance (Farley et al. 1995). As the classification scheme includes a heterogeneous set of variables, it is not always possible to develop a well-defined set of hypotheses. For instance, the dispositional traits sub-category might include determinants of sales performance that contribute to salespeople both over- and underestimating their own performance.
Hypotheses for measurement method moderators

Self-report versus managerial report When determinantsales performance associations are based on self-rated measures of sales performance, the strength of the association may be higher due to common method bias (Podsakoff et al. 2003). The literature points to the fact that people generally appraise themselves as better and smarter than others do, which may lead to a "self-enhancing bias" (Leary and Kowalski 1990). For instance, salespeople's aptitudes (e.g., optimism) might positively affect their own estimation of job performance. Similarly, sales- 
Table 3 Intercorrelations among drivers of sales performance

\begin{tabular}{|c|c|c|c|c|c|c|}
\hline Predictor & RA & $\mathrm{CA}$ & AS & SK & WE & SP \\
\hline Role Ambiguity (RA) & {$[.77]$} & & & & & \\
\hline \multicolumn{7}{|l|}{ Number of effects } \\
\hline \multicolumn{7}{|l|}{ Cumulative sample size } \\
\hline Cognitive Aptitude (CA) & $.06(.10)$ & {$[.79]$} & & & & \\
\hline Number of effects & 3 & & & & & \\
\hline Cumulative sample size & 336 & & & & & \\
\hline Adaptive Selling (AS) & $-.15(.07)$ & $.41(.23)$ & {$[.82]$} & & & \\
\hline Number of effects & 3 & 4 & & & & \\
\hline Cumulative sample size & 861 & 301 & & & & \\
\hline Selling-Related Knowledge (SK) & $-.15(.21)$ & $.41(.11)$ & $.30(.20)$ & {$[.81]$} & & \\
\hline Number of effects & 4 & 4 & 4 & & & \\
\hline Cumulative sample size & 1,323 & 637 & 965 & & & \\
\hline Work Engagement (WE) & $-.16(.13)$ & $.28(.21)$ & $.32(.07)$ & $.13(.06)$ & {$[.78]$} & \\
\hline Number of effects & 24 & 3 & 4 & 8 & & \\
\hline Cumulative sample size & 6,136 & 637 & 792 & 1,534 & & \\
\hline Sales Performance (SP) & $-.25(.14)$ & $.23(.11)$ & $.27(.15)$ & $.28(.17)$ & $.23(.20)$ & [.84] \\
\hline Number of effects & 113 & 12 & 71 & 122 & 110 & \\
\hline Cumulative sample size & 27,832 & 1,928 & 14,547 & 29,910 & 25,238 & \\
\hline
\end{tabular}

people with a strong goal orientation might feel or think that they perform better. Therefore, we present the following hypothesis:

H1: Determinant-sales performance effect sizes are stronger when sales performance data are gathered from self-reports versus managerial reports.

Objective data versus managerial report Because managerial ratings of sales performance represent subjective judgments, they may be more susceptible to bias. Indeed, subjective and objective measures of job performance have been found non-exchangeable in multiple meta-analyses (e.g., Bommer et al. 1995; Ng et al. 2005). In general, when salespeople have a clear goal orientation we can expect them to be capable of attaining higher goals (number of actual sales). On the other hand, sales managers might underestimate or overestimate the salesperson's performance (they appraise one salesperson in comparison to others in their group). In this regard, Rich et al. (1999) demonstrated that a vast majority of the variants in managerial reports on sales performance are explained by factors other than objective sales productivity. Managerial performance ratings may incorporate job relevant aspects not reflected in objective sales performance such as organizational citizenship behaviors (MacKenzie et al. 1991, 1993). The most effective salespeople (more sales) are possibly not the best corporate citizens, so when managers consider their citizenship behavior as well, their sales performance may be rated lower. As a result, we propose the following hypothesis:

$\mathrm{H} 2$ : Determinant-sales performance effect sizes are stronger when sales performance is measured by objective data versus managerial reports.

Multi-item versus single-item measure Multi-item measures of sales performance are more likely to capture a comprehensive the sales performance construct (Churchill 1979; Henard and Szymanski 2001; Avila et al. 1988). If multiple items are used to measure performance, a more varied set of objective and subjective indicators is taken into consideration. Single items, in contrast, might provide too small a basis for comprehensiveness, risking the chance that important performance dimensions remain unobserved. Hence, the level of performance might show a downward bias. Thus, we propose the following hypothesis:

H3: Determinant-sales performance effect sizes are stronger when sales performance is measured with multiitem versus single-item measures.

Hypotheses for research context moderators

Services versus goods The offerings of salespeople who sell services are more intangible, inseparable, and perishable than those of salespeople selling goods (Parasuraman 
et al. 1985). Selling services therefore is typically an interactive process, in which salespeople co-produce services together with customers (e.g., Zeithaml et al. 1996; Bettencourt et al. 2002). There are two interpretations for this. Services provide salespeople with more opportunities to affect the outcome of a sale. However, as customers also participate in the sale and formulate their own needs, only those salespeople who can manage their customer's attention and time will succeed. This complexity is less of an issue when salespeople sell goods since consumers/ customers have more opportunities to inform themselves about the quality/price relationship of the goods prior to the sales conversation (e.g., using Internet). Therefore, we propose the following hypothesis:

H4: Determinant-sales performance effect sizes are stronger for selling services versus selling goods.

Consumers versus business customers Selling to business buyers as opposed to consumers is likely to involve more complex and lengthy decision processes, more and bettertrained buying-decision participants, and more rational buying criteria (Dawes et al. 1998; Manning et al. 2010, p.162). Whereas selling to consumers habitually takes place within organizational boundaries (e.g., retail stores or call centers), salespeople selling to business buyers generally operate as "boundary spanners" outside of their own organizations (e.g., Nygaard and Dahlstrom 2002) and must deal with factors beyond their control. Salespeople working inside the organizational boundary have more control over transactions than those working in large buying centers. Their internal environment provides them with resources to accomplish goals but it also provides distractions (e.g., socializing with colleagues). Consequently, we propose the following hypothesis:

H5: Determinant-sales performance effect sizes are stronger for selling to consumers versus selling to business customers.

Internal versus external governance Inspired by transactioncost economics (TCE), Anderson and Schmittlein (1984, p. 386) distinguish between salespeople operating under two governance forms. An integrated governance mode conceives salespeople as "direct" sales employees of a firm that operates under internal (i.e., hierarchical) governance. Alternatively, external (i.e., market) governance implies salespeople who operate as independent "reps" offering their selling services. The key driver of being able to work independently is largely a motivational and dispositional issue: those who can make decisions related to work priorities or have an optimistic outlook thrive. Not all salespeople possess strong entrepreneurial characteristics and thrive more while operating in a hierarchical government structure where colleagues and managers provide support (yet, as argued earlier, they can also be distracted). Therefore, we propose the following hypothesis:

H6: Determinant-sales performance effect sizes are stronger for selling under internal versus external governance.

Hypotheses for sales-type moderators

Output versus behavioral Outcome versus behavioral types of sales performance represent two "very different managerial philosophies" (Oliver and Anderson 1994, p. 54). Drawing upon agency theory (e.g., Eisenhardt 1989), we reason that the selling firm (principals) and its salespeople (agents) have divergent goals (Anderson and Oliver 1987) and sales firms have imperfect information about the efforts of salespeople. As a selling firm's goal is typically to achieve sales performance in outcome terms, salespeople who can cope with uncertainty due to their personality traits (optimism), flexibility (adaptive selling) or motivation (ability to make work choices) thrive even when they also benefit from the internal resources of the firm (colleagues, coaching etc). It has recently been argued that salespeople under outcome-based control allocate their resources more intelligently (Ahearne et al. 2010a). We would expect determinants of sales performance to stimulate less in a behavior-based context. Consequently, we propose the following:

H7: Determinant-sales performance effect sizes are stronger when sales performance is output-based versus behavior-based.

Relationship quality versus traditional Salespeople have been argued to generate performance outputs in two conceptual categories, or distinct sales "roles": (1) relationship quality outputs and (2) traditional outputs (e.g., Morgan and Hunt 1994; Weitz and Bradford 1999). As a consequence of these different sales performance types, it is suggested that "the knowledge, skills and abilities of traditional salespeople differ from those of relationship managers" (Weitz and Bradford 1999, p. 242). Indeed, scholars have argued that the strength of determinant-sales performance associations vary for traditional-type vis-àvis relational-type sales performance outputs, because the two selling paradigms differ in what they require from salespeople (Crosby et al. 1990; Wotruba 1996). Salespeople working in a context wherein performance entails developing and maintaining relationships use more selfinitiative, are good communicators and can cope with 
different role expectations from both the internal and external role set. This recalls Crosby, Evans and Cowles' (1990, p. 77) expression that "continued sales opportunities are a privilege earned through attention to the perceived quality of the customer relationship." Thus, we propose the following:

H8: Determinant-sales performance effect sizes are stronger for relationship quality output versus traditional sales output.

\section{Results}

First, we present the results of the analysis of significance and relative strength of the antecedents of sales performance for which we used a combination of bivariate (Table 2) and multivariate causal model analyses (Table 4). Next, we show the results of our moderator analysis that investigated differences in determinant-sales performance relationships. Before doing so, we note in Table 3 that the cognitive aptitude-sales performance relationship is based upon a relatively smaller number of studies than other more frequently studied antecedents.

\section{Relevant drivers for salesperson performance}

Bivariate analysis The results in Table 2 expose the significance and relative strength of the drivers of salesperson performance. For 4 out of 18 determinants, our bivariate data indicates significant antecedent-sales performance associations: role ambiguity $(r=-.25, p<.05)$, cognitive aptitude $(r=.23, p<.05)$, degree of adaptiveness $(r=.27, p<.05)$, and selling-related knowledge $(r=.28$, $p<.05)$.

Multivariate causal model estimation Table 4 shows the results of our multivariate causal model. Overall, the model

Table 4 Multivariate causal model results: drivers of sales performance

\begin{tabular}{lc}
\hline Predictor & Standardized coefficient (ß) \\
\hline Role Ambiguity & $-.25(.12)^{*}$ \\
Cognitive Aptitude & $.23(.11)^{*}$ \\
Degree of Adaptiveness & $.27(.12)^{*}$ \\
Selling-Related Knowledge & $.28(.12)^{*}$ \\
Work engagement & $.23(.11)^{*}$ \\
$\mathrm{R}^{2}$ (adjusted) & .320 \\
$\mathrm{~F}$ (p-level) & $15.526(<.001)$ \\
Maximum variance inflation factor & 1.008 \\
\hline
\end{tabular}

$* p<.05$ predicts $32 \%$ of the variance in sales performance. ${ }^{5}$ The results of the multivariate causal model analysis demonstrate that role ambiguity $(\beta=-.25, p<.05)$, cognitive aptitude $(\beta=.23, p<.05)$, degree of adaptiveness $(\beta=.27$, $p<.05)$, and selling-related knowledge $(\beta=.28, p<.05)$ are significant drivers for salesperson performance. In addition, the model demonstrates a significant effect for work engagement $(\beta=.23, p<.05)$. Overall, the combination of bivariate and multivariate causal model analyses generates a consistent rank order of relative strength of the antecedents of sales performance, increasing the validity of this study.

\section{Moderator analysis}

Based on the results shown in Table 5, the following observations can be made. First, in part conforming to our hypotheses, all moderating variables affect determinantsales performance relationships. This supports our H1, H2, $\mathrm{H} 3, \mathrm{H} 4, \mathrm{H} 5, \mathrm{H} 6, \mathrm{H} 7$ and $\mathrm{H} 8$ in general. However as this meta-analysis covers many factors, these results need careful interpretation. Second, 11 of 18 moderator regression models account for a statistically significant portion of the variance in effect sizes between determinants and sales performance. ${ }^{6}$ Third, a closer look reveals that subcategoryperformance relationships seemingly most affected by moderators are motivation (cognitive choice: .23; work engagement: .20, and goal orientation: .15), aptitude (cognitive aptitude: .66; dispositional traits: .16, and identity: .11) and the external environment (.17). In the following section, we interpret how the subcategory performance relationships are affected by the different moderators. The insights gained here contribute to our interpretation of the results in general. Variables significant in the multivariate causal model estimation are italicized.

Moderator impact of measurement method

Self-report versus managerial report Dispositional trait $(\beta=.21, p<.01)$ and supervisory leadership determinants $(\beta=.15, p<.01)$ become stronger predictors of performance when self-reports are used. This might indicate that a person's disposition positively affects self-appraisals and shows that leadership style evokes an upward bias of sales performance, which possibly suggests a halo effect. For example, supportive transformational leaders may enhance

\footnotetext{
${ }^{5}$ The model results were tested for violations of standard assumptions including multicollinearity and heteroscedasticity; we found none. We tested for correct specification, using the Ramsey (1969) omitted variable test and found no support for omitted variables.

${ }^{6}$ We checked regressions on the publication year of the study (or year of public availability in the case of unpublished material).
} 


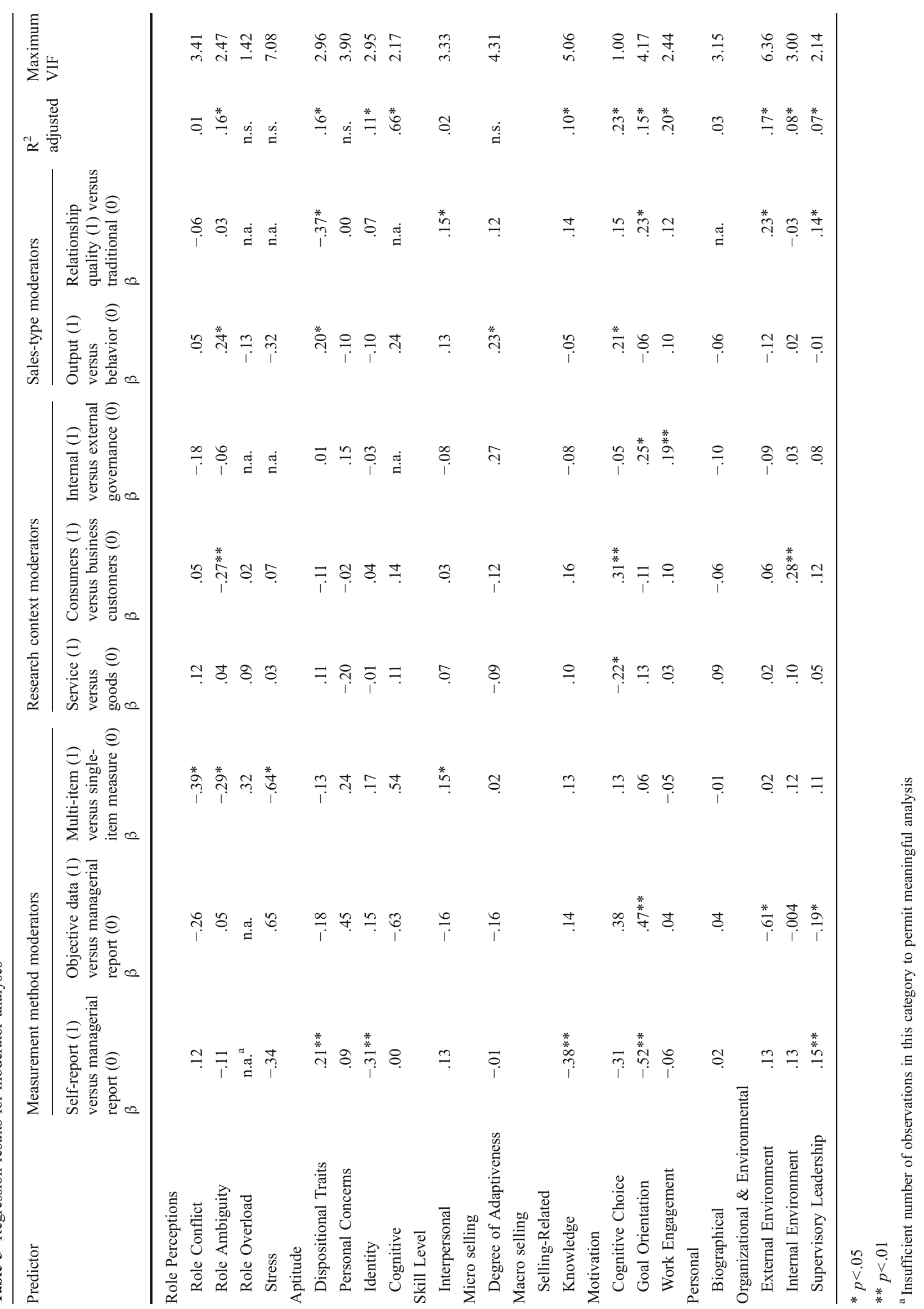


salespeople's self-perceptions, which in turn could motivate them to appraise their own sales performance higher. On the other hand, identity $(\beta=-.31, p<.01)$, selling-related knowledge $(\beta=-.38, p<.01)$ and goal orientation determinants $(\beta=-.52, p<.01)$ have stronger relationships with sales performance when performance data are based on managerial reports, vis-à-vis self-reports. Possibly managers appraise salespeople as more effective when salespeople have a stronger sense of self, possess more marketing insight, and/or have a strong goal orientation.

Objective data versus managerial report When objective performance data are used, goal orientation determinants $(\beta=.47, p<.01)$ are stronger predictors of sales performance than when managerial reports are used. Apparently, salespeople's goal-directed pursuit allows them to focus on objective outcomes as they offer less freedom for change. Contrary to expectations, external environment $(\beta=-.61$, $p<.05)$ and supervisory leadership determinants $(\beta=-.19$, $p<.05$ ) have weaker relationships with performance based on objective data than with managerial reports. Salespeople cannot always control the external environment (e.g., competition might be more intense) and similarly, a manager's leadership priorities might include such factors as citizenship behaviors which may not be favorable to making sales.

Multi-item versus single-item measure When sales performance is measured by multi-item measures, the impact of role conflict $(\beta=-.39, p<.05)$, role ambiguity $(\beta=-.29$, $p<.05)$ and stress $(\beta=-.64, p<.05)$ on sales performance becomes weaker than when performance is measured with single-item performance measures. A closer look at the literature reveals that most measures of role perceptions are relatively coarse-grained and reflect general states of mind of salespeople, which may lead to weaker associations with multi-item measures of sales performance. The relationship between salespeople's interpersonal selling skills and performance is higher when multi-item measures are used $(\beta=.15, p<.05)$, which might indicate that social competences are desirable to attain sales performance along a broader range of dimensions.

\section{Moderator impact of research context}

Services versus goods The Churchill et al. (1985) metaanalysis showed several differences in effect sizes of sales performance for selling services versus selling goods. As argued above, services imply co-creation with both customer and salesperson playing key roles and probably this requires highly motivated salespeople (making choices or having stronger goals). This difference, mentioned in the literature as a key distinction, is less apparent in the present study. This might suggest two things: first, that selling goods inherently implies selling services (e.g., Vargo and Lusch 2004) and second, that customers of both goods and services have become better informed (e.g., via Internet) and play a key role in making the sale. In fact, the motivational cognitive choice of salespeople is less associated to sales performance in services selling. This may indicate that customers take on a more important role in the co-creation process than salespeople who persist in achieving their sales goals.

Consumers versus business customers In selling to consumers, cognitive choice $(\beta=.31, p<.01)$, and the selling firm's internal environment $(\beta=.28, p<.01)$ are more important determinants of sales performance. Selling to consumers involves sales interactions in less complex environments (e.g., no large buying centers) and is likely to attract relatively lower-educated sales employees (who prefer to operate in more protected and constrained selling environments). The ability to choose and expend persistent effort on a well-defined selling job and the characteristics of the internal environment of the selling firm may have stronger effects on performance in consumer contexts. However, in selling to business customers, where role sets are often larger, sales cycles are longer, the latent needs of buying centers are not always evident, and decision-making processes are not always transparent, role ambiguity ( $\beta=-.27, p<.01)$, which indicates that a salesperson cannot infer the role-set expectations, is a stronger predictor of sales performance.

Internal versus external governance In an internal sales force, work engagement (job involvement) $(\beta=.19, p<.01)$, and goal orientation (a strong sense of purpose) $(\beta=.25$, $p<.05$ ), are stronger predictors of sales performance. Similar to the consumer context, under internal governance salespeople are more inclined to engage in (managerially directed) non-selling behaviors (citizenship behavior) and will be rewarded accordingly (Anderson 1985, p. 236). Salespeople with the ability to focus on goals and who show engagement at work thrive.

Impact of sales-type moderator

Output versus behavioral As expected, when sales performance measures are output-based, the strength of determinant-sales performance associations becomes significantly stronger: role ambiguity $(\beta=.24, p<.05)$, dispositional traits $(\beta=.20, p<.05)$, degree of adaptiveness $(\beta=.23$, $p<.05)$ and cognitive choice $(\beta=.21, p<.05)$. In an outputoriented sales environment, the external sales goals challenge salespeople to bring out their best, which resounds with the recent findings of Ahearne et al. (2010a). Indeed, salespeople 
who can cope with role ambiguity, undertake their own actions, are flexible during conversations, and can work smarter thrive (e.g., Sujan et al. 1994).

Relationship quality versus traditional outputs In predicting relational sales performance, as opposed to predicting traditional sales performance, interpersonal skills $(\beta=.15$, $p<.05)$, goal orientation $(\beta=.23, p<.05)$, the external environment $(\beta=.23, p<.05)$ and supervisory leadership $(\beta=.14, p<.05)$ all seem more salient determinants. Apparently, interpersonal abilities, ability to deal with different people, remaining committed to a relationship and the support of managers (in terms of cognitive and emotional resources) in building and maintaining relationships are more salient determinants of relationship quality versus traditional type sales performance (e.g., making transactions). Against expectation, dispositional traits of salespeople relate stronger to traditional, than to relational performance $(\beta=-.37, p<.05)$. Thus, salesperson disposition seems a less important determinant for relational, vis-àvis transactional salespeople. Drawing on "trait activation" theory, which studies situational specifics of personality-job performance relationships, in general terms the personality traits of salespeople could be more valuable for the persuasive job demands needed to achieve traditional outputs, as compared to the job demands needed to achieve relationship quality outputs (Tett and Burnett 2003). Salespeople may be less interdependent on co-workers to achieve traditional sales output (Weitz and Bradford 1999), which could make the impact of salespeople's individual personality traits more salient.

\section{Discussion}

Having accomplished the goal of this study-a metaanalytical exploration of variables that predict sales performance since the work of Churchill et al. (1985) we present two major findings: (1) Combined bivariate and multivariate analysis show that five drivers of sales performance have an independent predictive effect on sales performance, in order of magnitude: selling-related knowledge (.28), degree of adaptiveness (.27), role ambiguity $(-.25)$, cognitive aptitude (.23) and work engagement (.23). They can be perceived as "empirical generalizations" reflecting "a pattern of regularity that repeats over different circumstances" (Bass and Wind 1995, p. 1). (2) Measurement methods, research contexts and sales types all significantly moderate many of the determinant-performance relationships. At this point, let us pose two questions relevant to both sales researchers and practitioners: First, How does our study contrast with the meta-analysis by Churchill et al. (1985)? Second, based upon Rosenthal's (1995, p. 190) recommendation on discussing meta-analytical findings: "Where are we, now that this (new) meta-analysis has been conducted?" Answering the first question requires a closer look at both studies, a fairly low-risk undertaking as it simply means observing and studying causal relationships and taking moderators into account (see Tables 4 and 5). Addressing the second question is a more precarious undertaking as it requires us to take a bird's-eye view of the data, to discover a pattern that signals (but probably does not indicate directly) an emergent common theme which might guide future research in selling and help managers shape their future sales forces.

In general, the present study reveals a different ranking of the drivers of sales performance than the Churchill et al. (1985) study. Whereas Churchill et al. (1985) showed the rank order of sales performance determinants (based on magnitude of the determinant-sales performance relationship) as role perceptions, skill level, aptitude, motivation, personal characteristics and organizational or environmental variables, our meta-analysis shows a somewhat different rank order: selling-related knowledge, degree of adaptiveness, role ambiguity, cognitive aptitude and work engagement. These differences might be attributed to the fact that in our study we used more finely grained subcategories based upon theoretical insight and judgment than the categories used in the Churchill et al. (1985) study. A closer look at both studies shows that they overlap largely: selling-related knowledge and adaptive selling are sub-categories of Churchill's skills category, cognitive abilities is a sub-category of Churchill's aptitude sub-category, role ambiguity is a sub-category Churchill's role perceptions category and work engagement is a subcategory of Churchill's motivation category.

This takes us to what can be learned from the differences and similarities of both studies. Keeping abreast of current literature in the fields of marketing, economics, and management, the authors of this study observe a predominant theme: we are moving towards a knowledge-intensive economy (e.g., Achrol and Kotler 1999; Adler 2001; Dean and Kretschmer 2007). Typical examples in marketing are the emergence of science-based industries such as life sciences (e.g., Stremersch and Van Dyck 2009), or hightech industries (John et al. 1999). The central role of knowledge also shows up in other aspects of our economy. For example: selling financial services to either consumer or industrial customers comes with knowledge about finance and economics, selling in a business-to-business environment comes with technical knowledge and/or knowledge about logistics. Even selling consumer products comes with knowledge about customer segments, pricing or knowledge about technical details of the product. It should be noted that as the pace of innovation increases, knowledge acquisition by the salesforce becomes more 
urgent and for many more challenging (e.g., Hauser et al. 2006). In short, in today's knowledge economy, knowledge has become an endogenous part of the creation of value in terms of innovation, production, marketing and selling of products and services (e.g., Achrol and Kotler 1999; Romer 1986; Vargo and Lusch 2004). Another aspect of the knowledge economy is that customers are now better informed than before; the Internet is a key driver in this regard, and places pressure on salespeople to possess knowledge that is scarce and unavailable to the customer. In this context, one of the challenges - if not the main challenge - salespeople face in a knowledge-intensive firm is that they must become knowledge brokers whose job it is to transfer knowledge about products to customers. More concretely, this means that salespeople must communicate how their products or services solve both the explicit and latent problems of their customers. This demands that salespeople acquire and possess knowledge about their products (at times the science behind their products), as well as about the way these products help their customers solve their problems (e.g., Ofek and Sarvary 2001; Vargo and Lusch 2004). This transference of knowledge predominantly takes place in conversations with customers during which customers learn to frame their own needs or issues in new ways, such that they can discover how solutions provided by the salesperson might fit their needs or solve their issues (e.g., Homburg et al. 2009). Markets for knowledge-intensive services or products, such as life sciences or high-tech industries also require an understanding of the dynamics of large buying centers. Not only must the salesperson be able to make contact with the people in a customers' buying center, but he/she must also establish contact with opinion leaders (e.g., lead customers or experts) and decision makers outside the customer's buying center, because they all affect the take-off of innovations in such markets (for a good overview see Stremersch and Van Dyck 2009). The salesperson must understand how buying centers relate to each other and how various personal influences or buying decisions might have to be synchronized. Once again, this competence is not only required with industrial customers but also in consumer markets. For instance, when consumers are opinion leaders and are well-informed (use Internet), the salespeople interacting with them also have to be well-informed and educated in novel trends. In short, these knowledge demands (sellingrelated knowledge) tax a salesperson's capacity to absorb knowledge, which is probably why salespeople should possess sufficient cognitive abilities to succeed in today's world of selling. These observations are in the back of our minds when we describe the five significant drivers of sales performance revealed by our study. Similar to Churchill et al., who underscored how determinants of sales performance are "influenceable" in terms of selec- tion, motivation, coaching and training by managers (1985, p. 117), we also discuss the implications of our findings for managers.

Selling-related knowledge This reflects the knowledge of both products and customers that is required to present and "co-create" solutions for customers, as Vargo and Lusch (2004) would argue. Concretely, it implies understanding the roles of specific buying-center members and what products or services mean for them (e.g., who is an "influencer" or "decision maker"). It also implies an understanding of how products or services diffuse over markets (e.g., who is an "early adopter" or a "late adopter"). More effective salespeople possess richer categorization systems, in terms of both who to approach, as well as when, what and how (e.g., Sujan et al. 1988). This sub-category has the highest correlation (.28) with sales performance (see Table 4). We reason that present-day salespeople have little time and need to allocate their scarce resources to market players (who increasingly represent international markets) who are most open to their messages or most relevant to their own firm at certain moments in time. For instance, by focusing on opinion leaders or lead users, salespeople can influence the take-off of products and services in markets and at the same time learn from key accounts (e.g., Stremersch and Van Dyck 2009). This ability to understand the "know-why" of a product, how it might produce a solution (know-how) and who will adopt it ("know-who") draws on the absorptive learning capacity of a salesperson. Hence it is not surprising the selling-related knowledge sub-category correlates notably with cognitive aptitude (.41) - and this despite the fact that this variable is scarcely used in the literature $(n=12)$. Probably, salespeople who undertake knowledge brokering need to position themselves as thought leaders (e.g., Stremersch and Van Dyck 2009). However, maintaining thought leadership status requires constant sourcing of knowledge from different domains or industries through networks; examples of such network ties are key accounts, but also other stakeholders, including universities and knowledge centers (e.g., Rodan and Galunic 2004). As we move into a knowledge-intensive economy, we expect a stream of research on how salespeople develop networks to source new and relevant knowledge, so that they can transfer this knowledge to their customers (e.g., Reibstein et al. 2009). In this regard, we call upon researchers in selling to empirically investigate the role of social-network related variables for achieving sales performance. We reason that "knowledge brokering" abilities (e.g., to access knowledge dispersed in networks) may become an important precursor for selling-related knowledge of salespeople (Hargadon 2002). We invite future researchers to operationalize knowledge brokering in sales and test the conjecture that knowledge brokering, 
conceivably mediated by selling-related knowledge and/or adaptive selling, predicts sales performance. Such future investigations may benefit from advanced methods such as (longitudinal) social-network analyses. The basic message for managers is that selling-related knowledge can be trained (e.g., salespeople can learn to ask and discover customer needs and priorities), and can be organized in the selling firm (e.g., recruiting people with specific network ties). In addition, salespeople can be trained how to communicate with colleagues from different departments (e.g., Kumar et al. 2008; Homburg et al. 2009). In industrial firms for example, most likely a large proportion of salespeople already possess a substantial amount of knowwhy (e.g., engineers, scientists) but need training in how to develop selling-related knowledge (i.e., sales engineers).

Degree of adaptiveness As a basic limitation of their metaanalysis, Churchill et al. (1985, p. 116) admit that the studies in their database did not focus on "dynamics making up the individual sales transaction" and speculate that the ability to tailor behavior to individual customers probably is a key determinant of sales performance. The empirical results of our meta-analysis substantiate exactly that: a salesperson's degree of adaptiveness is a significant driver of sales performance and, as the moderating analysis showed, this driver is stable across nearly all moderating conditions. Adaptive selling has typically been conceived as the capacity to utilize both declarative and procedural knowledge, to match selling strategy to client needs (e.g., Szymanski 1988; Saxe and Weitz 1982). Building on the insights from our study, we anticipate that the conceptualization of adaptive selling will likely undergo some change. First, in a knowledge-intensive economy, salespeople capable of sharing analogies (e.g., can explain "knowwhy" to spark the imagination of customers who do not always possess this knowledge), and can share "know-how" from cases (e.g., can explain how other customers - early adopters or lead users - use a product or service) will most likely thrive (e.g., Sarvary 1999; Gavetti and Rivkin 2005). Second, given recent advances in work on neurosciences and marketing, we expect innovative research on adaptive selling. Indeed, adaptive selling requires the ability to "mind read" customers, which calls for a salesperson to read the customer's intentions and needs. Not all salespeople seem able to do so. For instance, Dietvorst et al. (2009), using fMRI-based research, propose a sales specific theory of mind scale (similar to the adaptive selling concept). They show that this ability to imagine a customer's intentions is associated with a hard-wired network of brain nuclei activation. We expect more research in the future on how neuroscience might help researchers to understand what makes salespeople both adaptive and more effective. Insights into how salespeople use analogies, in addition to the neural mechanisms of adaptive selling might help sales managers to train salespeople as well as recruit salespeople who possess the abilities to be adaptive.

Role ambiguity This is and remains an important (negative) driver of sales performance. Not surprisingly, when role expectations are clear, the salesperson performs better. A closer look at Table 3 shows that this variable is not substantially correlated with any of the significant predictor variables. Table 5 shows that the role ambiguity-sales performance relationship is moderated by how sales performance is measured. One possible interpretation could be that the definition of the role-ambiguity concept needs further development. However, it is likely that as we are entering a more turbulent and knowledge-intensive economy, role ambiguity is and will be an inherent condition of a salesperson's job (Moncrief and Marshall 2005). Hence, managers will need to recruit, select, develop, and retain those salespeople qualified to cope with role ambiguity embedded in the selling job, and who have the ability and motivation to sculpt or craft their job and the roles that come with it (Wrzesniewski and Dutton 2001). In this regard, Singh (1998) argued that role ambiguity might provoke salespeople to develop and nurture coping mechanisms that might make them more resilient to role stress. Table 2 shows that role ambiguity was the second most frequently studied topic in the past 25 years of sales research. Should interest in this topic now be waning? Should research interest not turn, instead, to knowledgeintensive firms, for instance, where boundary-spanning networks both inside and across selling and buying firms are important routes for salespeople to source product/salesrelated knowledge from colleagues and customers, including their expectations (e.g., Weitz and Bradford 1999). These personal networks are informal by definition and must be built and maintained, as well as sculpted and crafted by the (adaptive) salesperson (Achrol and Kotler 1999; Weitz and Bradford 1999). In this regard, we invite sales force researchers to explore the role of salesforce leadership and address the question of how to manage, lead, and coach the salesperson to make sense of an increasingly ambiguous sales environment. In some selling contexts, leadership should be conceived as a protective (buffering) managerial function, whose focus should be on reducing role ambiguity, for instance, through communication and feedback (Jaworski and Kohli 1991; Johlke et al. 2000). Transformational leadership, for instance, has been shown to reduce role ambiguity and guide salespeople's "values, goals and aspirations" (MacKenzie et al. 2001, p. 118).

Cognitive aptitude This is the "new kid on the block" in this meta-analysis. A closer look at Table 2 shows that this sub-category only captures 12 correlations. In a knowledge- 
intense economy, salespeople selling knowledge-based solutions are called upon to transfer knowledge (knowwhy) from their own firm to the firms of various customers (e.g., Verbeke et al. 2008). Intelligent salespeople shape how customers conceptualize their own needs and how the product or service of the selling firm relates to this view. Salespeople high on cognitive aptitude can make better variations in their messages and are likely to be more effective "information sellers" (Sarvary 2002). They help customers understand their issues and substantiate their ideas with quantitative (financial) data, an emerging requirement in selling (e.g., Reibstein et al. 2009). Salespeople communicate with various members of the buying center (Dawes et al. 1998), and should be capable of working with Sales Force Automation (SFA) and/or Customer Relationship Management (CRM) systems (e.g., Speier and Venkatesh 2002; Sundaram et al. 2007). Indeed, following Schmidt and Hunter's (2004) theorizing on the IQ-job performance relationship, salespeople are more likely to "acquire more job knowledge and acquire it faster", and consequently perform better (p. 170). In short, salespeople with sufficient cognitive abilities will excel. Since cognitive ability is a stable personality trait, the managerial implication is that firms will most likely hire salespeople high on cognitive abilities. However, as Verbeke et al. (2008) show, cognitive abilities should be complemented by other abilities, especially social skills, to prevent firms from only hiring "competent jerks" which can result in dissatisfied customers. Surprisingly, cognitive abilities is a relatively under researched topic (Table 2 demonstrates it is the smallest sub-category with only 12 correlations). However, we expect cognitive aptitude to play a major role in future research on selling and argue that the cognitive ability-sales performance relationship deserves further investigation. Please note, although IQ cannot be influenced as it is a trait, managers can be influenced to hire people with high IQs. On a similar tangent, as knowledge intensity is full of innovation, does this mean salespeople with low IQs would have lower chances of surviving "the next innovation"? How could sales managers ensure their survival? Questions like these impose challenges not only on research but also on ethics and managerial issues. As far as research is concerned, an interesting approach would be to study how IQ is related to selling-related knowledge; for instance, do salespeople with a high IQ read their market differently? Table 3 demonstrates a high correlation for this item, but then the question becomes, what does this high correlation mean? This is especially true in view of the increasing complexity - or knowledge intensity - of the selling environment (e.g., Marshall et al. 2003) that is becoming more cognitively demanding for salespeople. For instance, new research on mediators and (cross-level) moderators of the cognitive ability-sales performance association could enhance the field's understanding of how, when and why cognitive abilities are relevant to successful sales.

Work engagement Personal networks, both in and beyond the selling firm (including the buying firm), are important means through which salespeople of the future will source and transfer knowledge. Yet, colleagues and customers will always be protective of who they choose to work (reciprocate) with and probably want to know what a salesperson can do for them. Salespeople who are leaders, engaged, proactive and willing to work with and for others (e.g., citizenship behaviors) will most likely find support from both colleagues and customers (e.g., Homburg et al. 2002). The managerial implication is that dedicated salespeople should be motivated to take responsibility for their job, and maintain a proactive attitude. Future research on how organizations could influence salesperson engagement would be particularly valuable. In this respect, authors have recently theorized potential physiological correlates (e.g., Heaphy and Dutton 2008). While current empirical work in this area is sparse, we argue that an investigation into how salespeople's physiological attributes (e.g., vitality) might determine engagement and performance would contribute importantly to the field.

As our dataset represents the available literature on sales performance, it allows us to identify a number of domains where the available research is scarce while further research seems promising. First is research on determinants of sales performance with relationship quality output variables. An important metric that most firms these days want to achieve is their long-term relationship quality with customers (e.g., Weitz and Bradford 1999). At present, research on sales performance in terms of relationship quality output variables is extremely limited compared to the vast amount of research on sales performance measured by traditional output variables. Indeed, in view of the changing nature of sales, some authors argue that salespeople of the future will have a great need of knowledge, skills and abilities that enable them to be effective relationship managers and trusted advisors (e.g., Verbeke et al 2008; Weitz and Bradford 1999). Hence, sales research using relationship quality output variables could offer a substantial contribution to the field.

Second, our study reveals the significant drivers and moderators of individual salesperson performance. However, we would like to point out the contrast between extant sales literature and the increasing practice today of organizing salespeople in selling teams (e.g., Weitz and Bradford 1999). In light of this, we call upon future researchers to investigate whether or not the insights from our meta-analysis into what drives salesperson performance can be generalized and treated as (aggregated) team-level 
determinants of sales team performance. Recently, scholars in organizational behavior have suggested that determinantperformance relationships at the individual versus the team level may differ importantly (e.g., Chen et al. 2007; DeShon et al. 2004). Indeed, as Ahearne et al. (2010b, p. 4) recently noted: "We do not know which of these insights [into salespeople as individuals] can be generalized to the sales team-level." For instance, while our data informatively show that selling-related knowledge and cognitive aptitudes significantly drive salesperson performance, they should be interpreted with caution when applied to the aggregate analytical level of selling teams. We propose future research that explores whether the aggregated (group-level) knowledge, adaptability, role ambiguity, intelligence, and engagement of a sales team significantly explains sales team performance. A further step in this direction may be to investigate how diversity (i.e., heterogeneity) of a sales team along these variables affects its performance.

Third, our study investigates drivers (input variables) of sales performance (output variable). Yet, the sales performance construct is becoming increasingly complex. We argue that while the modern-day practice of selling suggests that multiple conceptual or substantive types of sales performance achievements exist, exploration of the operationalizations of sales performance used as an output variable in primary studies in our dataset shows that sales scholars have generally been insensitive to such differentiations. This limits the ability of our meta-analysis to classify performance-as measured in extant sales literature-into different conceptual or substantive types. We call upon future scholars to address a more fundamental question: what constitutes sales performance in today's economy? Or, what is the nomological net of sales performance? We believe that this would explore a fruitful avenue of future research. Indeed, the widely used sales performance scales of Behrman and Perreault (1982, p. 357) were based on their analysis of "the job of industrial salespersons." However, based on a stream of literature on the evolving sales function, we speculate that revisiting Behrman and Perrault's analysis in the present world of selling could well demonstrate that the sales job has changed considerably since then (e.g., Moncrief and Marshall 2005). We call upon future researchers to develop and test theories about the (conceptual) multidimensionality of the sales performance construct. For instance, the "traditional output performance" category could be split into quality outputs (e.g., making sales with high profit margins) and quantity outputs (e.g., achieving high sales volumes) or, efficient performance (e.g., achieving high lead-to-deal conversion ratios) versus effective performance (e.g., achieving sales targets). Future research developing more ecologically relevant scales of sales performance has a great potential to contribute to the field and as a result, future sales meta-analyses would be able to test the moderating impact of a broader range of sales performance types. Indeed, building and testing theories about the conceptual multidimensionality of sales performance, permits future sales meta-analyses to investigate moderating effects of different conceptually oriented approaches to sales performance.

In short, a bird's eye view of the data indicates that as we grow into a knowledge-intensive and science-based economy, salespeople will function more as knowledge brokers who transfer knowledge to customers in either industrial or consumer contexts. This requires salespeople with sufficient cognitive abilities who can absorb knowledge, work cooperatively with diverse team members, tailor messages to an increasingly complex audience of stakeholders, and shape the minds of their customers. We would like to point out that the results of this study are not entirely different from the meta-analysis by Churchill et al. (1985), but the nuances revealed by the finely grained subcategories (especially cognitive aptitude) have inspired us to frame salespeople as knowledge brokers. We invite researchers of the future to focus on this research topic in the field of personal selling. More importantly, we suggest that researchers take an international, experimental and team perspective on the issue.

Acknowledgments The authors express their appreciation to Gert Goris, Librarian of Erasmus University, for his assistance in acquiring the necessary studies, and ISAM for financial sponsoring.

Open Access This article is distributed under the terms of the Creative Commons Attribution Noncommercial License which permits any noncommercial use, distribution, and reproduction in any medium, provided the original author(s) and source are credited.

\section{References}

Achrol, R. S., \& Kotler, P. (1999). Marketing in the network economy. Journal of Marketing, 63(4: Special Issue), 146-163.

Adler, P. S. (2001). Market, hierarchy, and trust: the knowledge economy and the future of capitalism. Organizational Science, 12 (2), 215-234.

Ahearne, M., Rapp, A., Hughes, D., \& Jindal, R. (2010a). Managing salesforce product perceptions and control systems in the success of new product introductions. Journal of Marketing Research, 47 (3), 424-434.

Ahearne, M., MacKenzie, S. B., Podsakoff, P. M., Mathieu, J. E., \& Lam, S. K. (2010b). The role of consensus in sales team performance, Forthcoming in Journal of Marketing Research, XLVI.

Ambrose, M. L., \& Kulik, C. T. (1999). Old friends, new faces: motivation research in the 1990s. Journal of Management, 25(3), 231-292.

Anderson, E., \& Schmittlein, D. C. (1984). Integration of the sales force: an empirical examination. Rand Journal of Economics, 15 (3), 385-395. 
Anderson, E. (1985). The salesperson as outside agent or employee: a transaction cost analysis. Marketing Science, 4, 234-254.

Anderson, E., \& Oliver, R. L. (1987). Perspectives on behavior-based versus outcome-based sales force control systems. Journal of Marketing, 51, 76-88.

Avila, R. A., Fern, E. F., \& Mann, O. K. (1988). Unraveling criteria for assessing the performance of sales. The Journal of Personal Selling \& Sales Management, 8(1), 45-54.

Bagozzi, R. P. (1978). Salesforce performance and satisfaction as a function of individual difference, interpersonal, and situational factors. Journal of Marketing Research, 15, 517-531.

Bass, F. M., \& Wind, J. (1995). Introduction to the special issue: empirical generalizations in marketing. Marketing Science, 14(3), G1-G6.

Behrman, D. N., \& Perreault, W. D. (1982). Measuring the performance of industrial salespersons. Journal of Business Research, 10, 355370 .

Behrman, D. N., \& Perreault, W. D. (1984). A role stress model of the performance and satisfaction of industrial salespersons. Journal of Marketing, 48, 9-21.

Bettencourt, L. A., Ostrom, A. L., Brown, S. W., \& Roundtree, R. I. (2002). Client co-production in knowledge-intensive business services. California Management Review, 44(4), 100-128.

Bommer, W. H., Johnson, J. L., Rich, G. A., Podsakoff, P. M., \& Mackenzie, S. B. (1995). On the interchangeability of objective and subjective measures of employee performance: a metaanalysis. Personnel Psychology, 48(3), 587-605.

Brown, S. P., \& Peterson, R. A. (1993). Antecedents and consequences of salesperson job-satisfaction: meta-analysis and assessment of causal effects. Journal of Marketing Research, 30(1), 63-77.

Brown, T. J., Mowen, J. C., Donavan, D. T., \& Licata, J. W. (2002). The customer orientation of service workers: personality trait determinants and effects on self- and supervisor performance ratings. Journal of Marketing Research, 39, 110-119.

Campbell, J. P., \& Pritchard, R. D. (1976). Motivation theory in industrial and organizational psychology. In M. D. Dunnette (Ed.), Handbook of industrial and organizational psychology. Chicago: Rand McNally.

Chakravarthy, B. S., \& Doz, Y. (1992). Strategy process research: focusing on corporate self-renewal. Strategic Management Journal, 13, 5-14.

Chen, G., Kirkman, B. L., Kanfer, R., Allen, D., \& Rosen, B. (2007). A multilevel study of leadership, empowerment, and performance in teams. Journal of Applied Psychology, 92(2), 331-346.

Cheung, C.-K., \& Chan, C.-F. (2005). Philosophical foundations of eminent Hong Kong Chinese CEO's leadership. Journal of Business Ethics, 60(1), 47-62.

Churchill, G. A., Jr. (1979). A paradigm for developing better measures of marketing constructs. Journal of Marketing Research, 16, 64-73.

Churchill, G. A., Jr., Ford, N. M., Steven, W. H., \& Walker, O. C., Jr. (1985). The determinants of salesperson performance: a metaanalysis. Journal of Marketing Research, 22, 103-118.

Cravens, D. W., Lassk, F. G., Low, G. S., Marshall, G. W., \& Moncrief, W. C. (2004). Formal and informal management control combinations in sales organizations the impact on salesperson consequences. Journal of Business Research, 57(3), 241-248.

Crosby, L. A., Evans, K. R., \& Cowles, D. (1990). Relationship quality in services selling: an interpersonal influence perspective. Journal of Marketing, 54(3), 68-81.

Dawes, P. L., Lee, D. Y., \& Dowling, G. R. (1998). Information control and influence in emergent buying centers. Journal of Marketing, 62, 55-68.

Dean, A., \& Kretschmer, M. (2007). Can ideas be capital? Factors of production in the postindustrial economy: a review and critique. Academy of Management Review, 32(2), 573-594.
DeShon, R. P., Kozlowski, S. W. J., Schmidt, A. M., Milner, K. R., \& Wiechmann, D. (2004). A multiple-goal, multilevel model of feedback effects on the regulation of individual and team performance. Journal of Applied Psychology, 89(6), 1035-1056.

Dietvorst, R. C., Verbeke, W. J. M. I., Bagozzi, R. P., Yoon, C., Smits, M., \& Van der Lugt, A. (2009). A sales force-specific theory-ofmind scale: tests of its validity by classical methods and functional magnetic resonance imaging. Journal of Marketing Research, XLVI, 653-668.

Eisenhardt, K. M. (1989). Agency theory: an assessment and review. Academy of Management Review, 14(1), 57-74.

Farley, J. U., Lehmann, D. R., \& Sawyer, A. (1995). Empirical marketing generalization using meta-analysis. Marketing Science, 14(3), G36-G46.

Ford, N. M., Walker, O. C., Jr., \& Churchill, G. A., Jr. (1983). Research perspectives on the performance of salespeople: Selected readings. Cambridge: Marketing Science Institute.

Ford, N. M., Walker, O. C., Jr., Churchill, G. A., \& Hartley, S. W. (1987). Selecting successful salespeople: A meta-analysis of biographical and psychological selection criteria. In M. J. Houston (Ed.), Review of marketing. Chicago: American Marketing Association.

Gavetti, G., \& Rivkin, J. W. (2005). How strategists really think. Harvard Business Review, 84(4), 465-483.

Geyskens, I., Steenkamp, J.-B. E. M., \& Kumar, N. (1998). Generalizations about trust in marketing channel relationships using meta-analysis. International Journal of Research in Marketing, 15(3), 223-248.

Glass, G. V., MacGaw, B., \& Smith, M. L. (1981). Meta-analysis in social research. Beverly Hills: Sage.

Gurevitch, J., \& Hedges, L. V. (1999). Statistical issues in ecological meta-analysis. Ecology, 80(4), 1142-1149.

Heaphy, D., \& Dutton, J. E. (2008). Positive social interactions and the human body at work: linking organizations and physiology. Academy of Management Review, 33(1), 137-162.

Hargadon, A. B. (2002). Brokering knowledge: linking learning and innovation. Research in Organizational behavior, 24, 41-85.

Hauser, J., Tellis, G., \& Griffin, A. (2006). Research on innovation: a review and agenda for marketing science. Marketing Science, 25 (6), 687-717.

Hedges, L. V., \& Olkin, I. (1985). Statistical methods for metaanalysis. Orlando: Academic.

Henard, D. H., \& Szymanski, D. M. (2001). Why some new products are more successful than others. Journal of Marketing Research, $38,362-375$.

Homburg, C., Wieseke, J., \& Bornemann, T. (2009). Implementing the marketing concept at the employee-customer interface: the role of customer need knowledge. Journal of Marketing, 73, 64-81.

Homburg, C., Workman, J. P., \& Jensen, O. (2002). A configural perspective on key account management. Journal of Marketing, $66,38-60$.

Huffcutt, A. I., \& Arthur, W., Jr. (1995). Development of a new outlier statistic for meta-analytic data. Journal of Applied Psychology, $80(2), 327-334$.

Hunter, J. E., \& Hunter, R. F. (1984). Validity and utility of alternative predictors of job performance. Psychological Bulletin, 96(1), 7298.

Hunter, J. E., \& Schmidt, F. L. (2004). Methods of meta-analysis: Correcting error and bias in research findings. Thousand Oaks: Sage.

Janiszewski, C., Noel, H., \& Sawyer, A. G. (2003). A meta-analysis of the spacing effect in verbal learning. Journal of Consumer Research, 30(1), 138-149.

Jaworski, B. J. (1988). Toward a theory of marketing control: environmental context, control types, and consequences. Journal of Marketing, 52, 23-39. 
Jaworski, B. J., \& Kohli, A. K. (1991). Supervisory feedback: alternative types and their impact on salespeople's performance and satisfaction. Journal of Marketing Research, 28(2), 190201.

Johlke, M. C., Duhan, D. F., Howell, R. D., \& Wilkes, R. W. (2000). An integrated model of sales managers' communication practices. Journal of the Academy of Marketing Science, 28, 263-277.

John, G., Weiss, A. M., \& Dutta, S. (1999). Marketing in technologyintensive markets: toward a conceptual framework. Journal of Marketing, 63, 78-91. Special issue 1999.

Kanfer, R. (1990). Motivation theory and industrial and organizational psychology. In M. D. Dunnette \& L. M. Hough (Eds.), Handbook of industrial and organizational psychology. Palo Alto: Consulting Psychology.

Kirca, A. H., Jayachandran, S., \& Bearden, W. O. (2005). Market orientation: a meta-analytic review and assessment of its antecedents and impact on performance. Journal of Marketing, 69, 24-41.

Kohli, A. K. (1989). Effects of supervisory behavior: the role of individual differences among salespeople. Journal of Marketing, $53,40-50$

Kumar, V., Venkatesan, R., \& Reinatz, W. (2008). Performance implications of adopting a customer-focused sales campaign. Journal of Marketing, 72, 50-68.

Leary, M. R., \& Kowalski, R. M. (1990). Impression management: a literature review and two-component model. Psychological Bulletin, 107, 34-47.

Leigh, T. W., Pullins, E. B., \& Comer, L. B. (2001). The top ten sales articles of the 20th century. Journal of Personal Selling \& Sales Management, 21(3), 217-227.

Leong, S. M., Bush, P. S., \& John, D. R. (1989). Knowledge bases and salesperson effectiveness: a script-theoretical analysis. Journal of Marketing Research, 26(2), 164-178.

Lipsey, M. W., \& Wilson, D. B. (2001). Practical meta-analysis. Thousand Oaks: Sage.

MacKenzie, S. B., Podsakoff, P. M., \& Fetter, R. (1991). Organizational citizenship behavior and objective productivity as determinants of managerial evaluations of salespersons' performance. Organizational Behavior and Human Decision Processes, 50(1), 123-151.

MacKenzie, S. B., Podsakoff, P. M., \& Fetter, R. (1993). The impact of organizational citizenship behavior on evaluations of salesperson performance. Journal of Marketing, 57(1), 70-81.

MacKenzie, S. B., Podsakoff, P. M., \& Ahearne, M. (1998). Some possible antecedents and consequences of in-role and extra-role salesperson performance. Journal of Marketing, 62, 87-98.

MacKenzie, S. B., Podsakoff, P. M., \& Rich, G. A. (2001). Transformational and transactional leadership and salesperson performance. Journal of the Academy of Marketing Science, 29 (2), 115-135

Manning, G., Reece, B., \& Ahearne, M. (2010). Selling today: Creating customer value. Upper Saddle River: Prentice Hall.

Marshall, G. W., Goebel, D. J., \& Moncrief, W. C. (2003). Hiring for success at the buyer-seller interface. Journal of Business Research, 56, 247-255.

Maslach, C., Schaufeli, W. B., \& Leiter, M. P. (2001). Job Burnout. Annual review of psychology, 52(1), 397-422.

McAdams, D. P. (1993). The stories we live by: Personal myths and the making of the self. New York: Morrow.

McAdams, D. P. (1995). What do we know when we know a person? Journal of Personality, 63(3), 365-396.

McAdams, D. P. (1996). Alternative futures for the study of human individuality. Journal of Research in Personality, 30(3), 374388.

Moncrief, W. C., \& Marshall, G. W. (2005). The evolution of the seven steps of selling. Industrial Marketing Management, 34(1), $13-22$.
Morgan, R. M., \& Hunt, S. D. (1994). The commitment-trust theory of relationship marketing. Journal of Marketing, 58(3), $20-38$.

Ng, T. W. H., Eby, L. T., Sorensen, K. L., \& Feldman, D. C. (2005). Predictors of objective and subjective career success: a metaanalysis. Personnel Psychology, 58(2), 367-409.

Nygaard, A., \& Dahlstrom, R. (2002). Role stress and effectiveness in horizontal alliances. Journal of Marketing, 66(2), 61-83.

Ofek, E., \& Sarvary, M. (2001). Leveraging the customer base: creating competitive advantage through knowledge management. Management Science, 47(11), 1441-1456.

Oliver, R. L., \& Anderson, E. (1994). An empirical test of the consequences of behavior and outcome-based sales control systems. Journal of Marketing, 58(10), 53-67.

Palmatier, R. W., Gopalakrishna, S., \& Houston, M. B. (2006). Returns on business-to-business relationship marketing investments: strategies for leveraging profits. Marketing Science, 25(5), 477-493.

Parasuraman, A., Zelthaml, V. A., \& Beryy, L. L. (1985). A conceptual model of service quality and its implications for future research. Journal of Marketing, 49, 41-50.

Perreault, W. D., \& Leigh, L. E. (1989). Reliability of nominal data based on qualitative judgments. Journal of Marketing Research, 26, 135-148.

Podsakoff, P. M., MacKenzie, S. B., Lee, J.-Y., \& Podsakoff, N. P. (2003). Common method biases in behavioral research: a critical review of the literature and recommended remedies. Journal of Applied Psychology, 88(5), 879-904.

Premack, S. L., \& Hunter, J. E. (1988). Individual unionization decisions. Psychological Bulletin, 103, 223-234.

Ramsey, J. B. (1969). Tests for specification errors in classical linear least-squares regression analysis. Journal of the Royal Statistical Society. Series B, 31(2), 350-371.

Reibstein, D. J., Day, G., \& Wind, J. (2009). Guest editorial: is marketing academia losing its way? Journal of Marketing, 73, $1-3$.

Rentz, J. O., Shepherd, D. C., Tashchian, A., Dabholkar, P. A., \& Ladd, R. T. (2002). A measure of selling skill: scale development and validation. Journal of Personal Selling \& Sales Management, 22(1), 13-21.

Rich, G. A., Bommer, W. H., MacKenzie, S. B., Podsakoff, P. M., \& Johnson, J. L. (1999). Methods in sales research: apples and apples or apples and oranges? A meta-analysis of objective and subjective measures of salesperson performance. The Journal of Personal Selling \& Sales Management, 19(4), 41-53.

Rodan, S., \& Galunic, C. (2004). More than network structure: how knowledge heterogeneity influences managerial performance and innovativeness. Strategic Management Journal, 25, 541-562.

Romer, P. M. (1986). Increasing returns and long-run growth. Journal of Political Economy, 94(5), 1002-1037.

Rosenthal, R. (1979). The "File Drawer Problem" and tolerance for null results. Psychological Bulletin, 86(3), 638-641.

Rosenthal, R. (1995). Writing meta-analytic reviews. Psychological Bulletin, 118(2), 183-192.

Sarvary, M. (1999). Knowledge management and competition in the consulting industry. California Management Review, 4(2), 95-107.

Sarvary, M. (2002). Temporal differentiation and the market for second opinions. Journal of Marketing Research, XXXIX, 129-136.

Saxe, R., \& Weitz, B. A. (1982). The SOCO scale: a measure of the customer orientation of salespeople. Journal of Marketing, 19, 343-351.

Schmidt, F. L., \& Hunter, J. (2004). General mental ability in the world of work: occupational attainment and job performance. Journal of Personality and Social Psychology, 86(1), 162-173.

Singh, J., Goolsby, J. R., \& Rhoads, G. K. (1994). Behavioral and psychological consequences of boundary spanning burnout for 
customer service representatives. Journal of Marketing Research, 31, 558-569.

Singh, J. (1998). Striking a balance in boundary-spanning positions: an investigation of some unconventional influences of role stressors and job characteristics on job outcomes of salespeople. Journal of Marketing, 62, 69-86.

Sonnentag, S. (2003). Recovery, work engagement, and proactive behavior: a new look at the interface between non-work and work. Journal of Applied Psychology, 88(3), 518-528.

Speier, C., \& Venkatesh, V. (2002). The hidden minefields in the adoption of sales force technologies. Journal of Marketing, 66, 98-111.

Stremersch, S., \& Van Dyck, W. (2009). Marketing of life sciences: a new framework and research agenda for a nascent field. Journal of Marketing, 73, 4-30.

Sujan, H., Weitz, B. A., \& Kumar, N. (1994). Learning orientation, working smart and effective selling. Journal of Marketing, 58(3), $39-52$.

Sujan, H., Sujan, M., \& Bettman, J. R. (1988). Knowledge structure differences between more effective and less effective salespeople. Journal of Marketing Research, XXV, 81-86.

Sundaram, S., Schwarz, A., Jones, E., \& Chin, W. W. (2007). Technology use on the front line: how information technology enhances individual performance. Journal of the Academy of Marketing Science, 35(1), 101-112.

Szymanski, D. M. (1988). Determinants of selling effectiveness: the importance of declarative knowledge to the personal selling concept. Journal of Marketing, 52(1), 64-77.

Szymanski, D. M., \& Henard, D. H. (2001). Customer satisfaction: a meta-analysis of the empirical evidence. Journal of the Academy of Marketing Science, 29(1), 16-35.

Tellis, G. J. (1988). The price elasticity of selective demand: a metaanalysis of econometric models of sales. Journal of Marketing Research, 25(4), 331-341.

Tett, R. P., \& Burnett, D. D. (2003). A personality trait-based interactionist model of job performance. Journal of Applied Psychology, 88(3), 500-517.
Vargo, S. L., \& Lusch, R. F. (2004). Evolving to a new dominant logic for marketing. Journal of Marketing, 68, 1-17.

Verbeke, W., Frank, D. B., Bakker, A. B., \& Dietz, B. (2008). When intelligence is (Dys)functional for achieving sales performance. Journal of Marketing, 72, 44-57.

Vinchur, A. J., Schippmann, J. S., Switzer, F. S., \& Roth, P. L. (1998). A meta-analytic review of predictors of job performance for salespeople. Journal of Applied Psychology, 83(4), 586-597.

Viswesvaran, C., \& Ones, D. S. (1995). Theory testing: combining psychometric meta-analysis and structural equations modeling. Personnel Psychology, 48(4), 865-885.

Walker, O. C., Jr., Churchill, G. A., Jr., \& Ford, N. M. (1977). Motivation and performance in industrial selling: present knowledge and needed research. Journal of Marketing Research, 14, $156-168$.

Wang, G., \& Netemeyer, R. G. (2002). The effects of job autonomy, customer demandingness, and trait competitiveness on salesperson learning, self-efficacy, and performance. Journal of the Academy of Marketing Science, 30(3), 217-228.

Warr, P., Bartram, D., \& Martin, T. (2005). Personality and sales performance: situational variation and interactions between traits. International Journal of Selection and Assessment, 13(1), 87-92.

Weitz, B. A., \& Bradford, K. D. (1999). Personal selling and sales management: a relationship marketing perspective. Journal of the Academy of Marketing Science, 27(2), 241-255.

Weitz, B. A., Sujan, H., \& Sujan, M. (1986). Knowledge, motivation, and adaptive behavior: a framework for improving selling effectiveness. Journal of Marketing, 50(October), 174-191.

Wotruba, T. R. (1996). The transformation of industrial selling: causes and consequences. Industrial Marketing Management, 25(5), 327-339.

Wrzesniewski, A., \& Dutton, J. E. (2001). Crafting a job: revisioning employees as active crafters of their work. The Academy of Management Review, 26(2), 179-201.

Zeithaml, V. A., Berry, L. L., \& Parasuraman, A. (1996). The behavioral consequences of service quality. Journal of Marketing, 60(2), 31-47. 